AN INTRODUCTION TO THE ANALYSIS AND PROCESSING OF SIGNALS 
Other titles in Electrical and Electronic Engineering

G. B. Clayton: Data Converters

J. C. Cluley: Electronic Equipment Reliability, second edition

A. R. Daniels: Introduction to Electrical Machines

W. Gosling: A First Course in Applied Electronics

B. A. Gregory: An Introduction to Electrical Instrumentation and Measurement Systems, second edition

L. F. Lind and J. C. C. Nelson: Analysis and Design of Sequential Digital Systems

A. G. Martin and F. W. Stephenson: Linear Microelectronic Systems

A. Potton: An Introduction to Digital Logic

Trevor J. Terrell: Introduction to Digital Filters

G. Williams: An Introduction to Electric Circuit Theory 


\section{AN INTRODUCTION TO THE ANALYSIS AND PROCESSING OF SIGNALS}

\section{PAUL A. LYNN}

Reader in Electronic Engineering University of Bristol

Second Edition

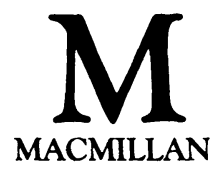


(C) Paul A. Lynn 1973, 1982

All rights reserved. No reproduction, copy or transmission of this publication may be made without written permission.

No paragraph of this publication may be reproduced, copied or transmitted save with written permission or in accordance with the provisions of the Copyright Act 1956 (as amended).

Any person who does any unauthorised act in relation to this publication may be liable to criminal prosecution and civil claims for damages.

First edition 1973

Reprinted 1977, 1979, 1980

Second edition 1982

Reprinted 1983, 1984 (with minor corrections), 1985

Published by

Higher and Further Education Division

MACMILLAN PUBLISHERS LTD

Houndmills, Basingstoke, Hampshire RG21 2XS

and London

Companies and representatives

throughout the world

ISBN 978-0-333-34030-1 ISBN 978-1-349-86054-8 (eBook)

DOI 10.1007/978-1-349-86054-8 


\section{Contents}

Preface

ix

\section{PART I SIGNAL ANALYSIS}

1 Background 3

1.1 Historical developments 3

1.2 Signal types and signal sources 4

1.3 The uses of signal theory 5

$\begin{array}{lll}1.4 & \text { Signal processors } & 6\end{array}$

2 Periodic Signals 7

2.1 Time-domain descriptions $\quad 7$

$\begin{array}{ll}2.2 \text { Frequency-domain descriptions } & 10\end{array}$

$\begin{array}{ll}2.3 \text { Orthogonal functions } & 12\end{array}$

$\begin{array}{lll}2.3 .1 & \text { Vectors and signals } & 12\end{array}$

2.3.2 Signal description by sets of orthogonal functions 15

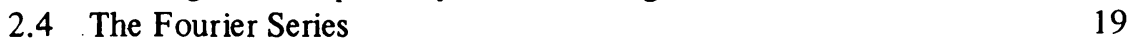

$\begin{array}{lll}2.4 .1 & \text { Evaluation of the coefficients } & 19\end{array}$

2.4.2 Choice of time origin, and wave form power 23

$\begin{array}{ll}2.4 .3 & \text { Some general comments } \\ & 27\end{array}$

$\begin{array}{ll}\text { Problems } & 28\end{array}$

3 Aperiodic Signals 30

$\begin{array}{lll}3.1 & \text { Introduction } & 30\end{array}$

3.2 The exponential form of the Fourier series 30

3.3 The Fourier transform 35

$\begin{array}{ll}\text { 3.3.1 Derivation } & 35\end{array}$

3.3.2 Examples of continuous spectra 37

3.3.3 Symmetry of the Fourier integral equations 41

3.3.4 Limitations of the Fourier transform 42

3.4 The Laplace transform 44

3.4.1 Relationship with the Fourier transform 44

3.4.2 Use of the Laplace transform 45 
3.4.3 The pole-zero description of a signal 48

$\begin{array}{lll}3.4 .4 & \text { Some further properties } & 52\end{array}$

Problems

4 Sampled-data Signals $\quad 57$

$\begin{array}{lll}4.1 & \text { Introduction } & 57\end{array}$

4.2 Mathematical description using the Dirac $(\delta)$ function 58

4.3 Spectra of sampled-data signals $\quad 59$

4.3.1 The discrete Fourier transform $\quad 59$

$\begin{array}{ll}\text { 4.3.2 The fast Fourier transform } & 62\end{array}$

$\begin{array}{lll}4.4 & \text { The } z \text {-transform } & 64\end{array}$

$\begin{array}{lll}4.4 .1 & \text { Introductory } & 64\end{array}$

$\begin{array}{ll}\text { 4.4.2 } z \text {-plane poles and zeros } & 65\end{array}$

$\begin{array}{ll}4.5 \text { Discussion } & 70\end{array}$

$\begin{array}{ll}\text { Problems } & 71\end{array}$

5 Random Signals $\quad 73$

$\begin{array}{lll}5.1 \text { Introduction } & 73\end{array}$

5.2 Elements of probability theory $\quad 75$

$\begin{array}{lll}5.2 .1 & \text { The probability of an event } & 75\end{array}$

$\begin{array}{lll}\text { 5.2.2 Joint and conditional probabilities } & 76\end{array}$

$\begin{array}{lll}\text { 5.2.3 The probability density function } & 78\end{array}$

$\begin{array}{lll}5.3 & \text { Amplitude distributions and moments } & 80\end{array}$

5.4 The autocorrelation and power spectral density functions 84

5.4.1 The spectral properties of random signals 84

$\begin{array}{lll}\text { 5.4.2 The autocorrelation function } & 85\end{array}$

5.4.3 The power spectral density function 88

$\begin{array}{ll}\text { 5.4.4 Application to random signals } & 90\end{array}$

5.5 Important types of random signal 93

$\begin{array}{lll}\text { 5.5.1 Stationary and ergodic signals } & 93\end{array}$

$\begin{array}{ll}\text { 5.5.2 Gaussian signals } & 94\end{array}$

5.5.3 Random binary signals: the binomial and Poisson distributions 96

$\begin{array}{ll}\text { 5.5.4 Pseudo-random signals } & 99\end{array}$

$\begin{array}{ll}\text { 5.5.5 Point-process signals } & 104\end{array}$

$\begin{array}{ll}\text { Problems } & 108\end{array}$

6 Signal Comparison $\quad 112$

$\begin{array}{lll}6.1 & \text { Introduction } & 112\end{array}$

$\begin{array}{ll}\text { 6.2 The cross-correlation function } & 113\end{array}$

$\begin{array}{ll}6.3 \text { The cross-spectral density function } & 116\end{array}$

$\begin{array}{ll}6.4 \text { Discussion } & 118\end{array}$

$\begin{array}{lr}\text { Problems } & 119\end{array}$ 


\section{PART II SIGNAL PROCESSING}

7. Signals and Systems

7.1 Introduction

7.2 Basic aspects of linear processing

7.2.1 Linear systems

$\begin{array}{ll}\text { 7.2.2 The frequency-domain approach } & 125\end{array}$

$\begin{array}{lll}7.2 .3 & \text { The time-domain approach } & 136\end{array}$

7.2.4 Examples of linear processes $\quad 143$

$\begin{array}{lll}7.3 & \text { Convolution, correlation, and filtering } & 145\end{array}$

$\begin{array}{lll}7.4 & \text { The processing of random signals } & 147\end{array}$

$\begin{array}{ll}7.5 \text { Nonlinear processing } & 154\end{array}$

Problems 155

8 Modulation and Sampling 158

$\begin{array}{ll}8.1 & \text { Introduction to modulation } \\ 8.2 & 158\end{array}$

$\begin{array}{ll}\text { 8.2 Signal sampling and reconstitution } & 160\end{array}$

$\begin{array}{ll}\text { 8.2.1 The sampling process } & 160\end{array}$

$\begin{array}{ll}\text { 8.2.2 Signal reconstitution } & 164\end{array}$

$\begin{array}{ll}\text { 8.3 Other modulation processes } & 166\end{array}$

$\begin{array}{lll}\text { 8.3.1 Signal truncation } & 166\end{array}$

$\begin{array}{ll}\text { 8.3.2 Amplitude modulation } & 169\end{array}$

$\begin{array}{ll}\text { 8.3.3 Frequency and pulse-code modulation } & 171\end{array}$

$\begin{array}{lr}\text { Problems } & 172\end{array}$

9 Filters 173

$\begin{array}{lll}9.1 & \text { Introduction } & 173\end{array}$

$\begin{array}{ll}\text { 9.2 General aspects of filter performance } & 174\end{array}$

$\begin{array}{lll}\text { 9.2.1 } & \text { Filter categories } & 174\end{array}$

9.2.2 Response in time and frequency domains 175

$\begin{array}{lll}9.3 & \text { Analogue filters } & 177\end{array}$

$\begin{array}{lll}\text { 9.3.1 General } & 177\end{array}$

$\begin{array}{ll}\text { 9.3.2 Some common filter types } & 178\end{array}$

$\begin{array}{lll}9.4 & \text { Digital filters } & 185\end{array}$

$\begin{array}{lll}\text { 9.4.1 General } & 185\end{array}$

$\begin{array}{ll}\text { 9.4.2 Some elementary digital filters } & 187\end{array}$

9.4.3 Hardware and software implementation 195

9.4.4 Filters with finite impulse responses (FIRs) 196

$\begin{array}{lll}\text { 9.4.4.1 Introduction } & 196\end{array}$

9.4.4.2 The moving-average filter 197

9.4.4.3 FIR designs based upon window functions 199

$\begin{array}{ll}\text { 9.4.4.4 Frequency-sampling filters } & 201\end{array}$

9.4.4.5 Recursive integer-multiplier designs 204 
9.4.5 Filters with infinite impulse responses (IIRs) 206

9.4.5.1 Introduction 206

9.4.5.2 Designs based upon choice of $z$-plane poles and zeros 207

$\begin{array}{ll}\text { 9.4.5.3 Impulse invariant filters } & 208\end{array}$

9.4.5.4 The bilinear transformation method 209

9.4.6 Further aspects of filter implementation $\quad 212$

Problems

10 Signal Recovery, Detection and Prediction $\quad 217$

$\begin{array}{lll}10.1 \text { Introduction } & 217\end{array}$

$\begin{array}{ll}10.2 & \text { Signal recovery } \\ 1 & 218\end{array}$

$\begin{array}{lll}\text { 10.2.1 Signals in wideband noise } & 218\end{array}$

10.2.2 Signals in narrowband noise $\quad 220$

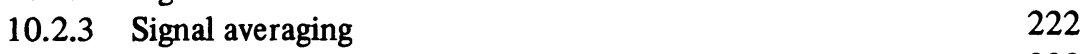

10.2.4 Optimum signal estimation 223

$\begin{array}{lll}\text { 10.2.4.1 Introduction } & 223\end{array}$

10.2.4.2 The Wiener filter $\quad 224$

10.2.4.3 The Kalman filter $\quad 229$

$\begin{array}{lll}10.3 & \text { Signal Detection } & 232\end{array}$

$\begin{array}{lll}\text { 10.3.1 Introduction } & 232\end{array}$

10.3.2 The matched filter 233

10.3.3 Pulse compression techniques 236

$\begin{array}{ll}\text { 10.3.4 Detection errors } & 238\end{array}$

10.4 Signal Prediction $\quad 241$

10.4.1 Introduction $\quad 241$

10.4.2 The Wiener predictor $\quad 242$

$\begin{array}{ll}\text { Problems } & 246\end{array}$

$\begin{array}{lr}\text { Postscript } & 248\end{array}$

Appendix: Some Useful Laplace Transforms $\quad 249$

$\begin{array}{lr}\text { Bibliography } & 250\end{array}$

$\begin{array}{lr}\text { Index } & 253\end{array}$ 


\section{Preface}

The aim of this book is to provide a concise and readable introduction to the theory of signal analysis and linear signal processing. Its level should make it suitable for the second and final years of degree courses in electrical and electronic engineering, and for other courses which deal with the analysis and processing of signals, records, and data of all types. A small proportion of the material covered would normally be reserved for courses of postgraduate standard.

The author of a book on signal theory-a subject already covered by a number of recent texts-must presumably offer some excuse for writing it. In my case, I have for some time felt the need for a book in this general area which neither assumes, nor develops, any detailed background in electrical circuits or techniques. The approach I have adopted is to discuss signals and signal processing from what is generally called a 'systems' viewpoint: in other words, the text does not involve itself with the details of electrical or electronic signal processors, nor does it concentrate on those types of signal which are largely or exclusively the concern of electrical and electronic engineering. I hope and believe, however, that students of electrical engineering will find the text relevant to courses on communications and linear systems as well as on signal theory, and that it will help them to fit much of their work on electric circuits and systems into a more general framework. I also trust that the approach adopted will make the text useful to workers in other fields where signals and data are important, such as other branches of engineering, physics, medicine and certain areas of social science and economics. With the latter in mind, I have tried to keep the mathematics as straightforward as possible, and to assume knowledge of nothing more advanced than basic integral calculus and the elementary manipulation of complex numbers. A further advantage of omitting detailed work on electrical circuits and systems is that it makes the task of describing basic aspects of signal theory in a short book that much more manageable.

I hope it may not seem unreasonable if I claim some novelty in content as well as in general approach. I have paid rather more attention to sampled-data signals than is usual in a book of this length, for several reasons. Electronics is becoming increasingly 'digital', as witnessed, for example, by the expanding use of pulse-code modulation for communications systems; and the digital computer is now widely used for the storage, analysis and processing of signals and data of all types. A further important reason for this emphasis lies in my belief that many central concepts of signal processing-for example convolution and correlation-are 
more easily grasped wher, applied to sampled-data signals. This approach has given me an excuse to include a substantial section on digital filters, which makes this book one of the first to deal with this important topic at an introductory level.

In rather more detail, chapters 2 and 3 give fairly conventional introductions to signal analysis by Fourier and Laplace methods, although limitations of space make it impossible to do proper justice to these powerful techniques. Chapter 4 deals with sampled-data signals and introduces the $z$-transform: from this point on, no special distinction is made between continuous and sampled-data signals, and later chapters illustrate concepts by reference to either or both types of function. The reader is therefore encouraged to tackle chapter 4 before proceeding, even if his main interest lies in continuous (analogue) signals and systems. The remainder of the book requires little introduction, except to say that the length of a chapter reflects only the amount of material I have thought appropriate to include under a particular heading. Chapter lengths therefore vary widely, and the longer ones are not intended to be read (even less digested) at one sitting. Indeed, it may be helpful to point out that the only part of chapter 5 ('Random Signals') which is important for an understanding of later chapters is section 5.4, which deals with autocorrelation and power spectral density functions: section 7.4 may also be omitted by the reader with little interest in random signals.

It is a pleasure to thank my colleague, G. A. L. Reed, for his many helpful suggestions and comments on the manuscript; and to record my debt to Professor B. McA. Sayers, of the Engineering in Medicine Laboratory in the Electrical Engineering Department at Imperial College, London, who first introduced me to many of the ideas covered in this book. Finally, my thanks are due to Miss V. Mackintosh and Miss L. Jackson who have tackled the typing with great competence and good humour. 


\section{Preface to the Second Edition}

The nine years since this book was first published have witnessed the remarkable growth of microelectronics. In the preface to the first edition, I noted that electronics was becoming increasingly digital, and the major impact of microelectronics has of course been in this area. Powerful microprocessors and computers, together with the digital signal analysis and processing techniques they offer, are now available at modest cost to almost anyone who requires them. This has been reflected in the large number of texts on digital systems, filters and processing which have appeared in the last five years or so. However, many of these texts (and, to an even greater extent, research papers) remain more or less inaccessible to the non-specialist, including the engineer 'brought up on' analogue circuits, systems and techniques. For this reason I hope that this book, which covers both analogue and digital approaches, and makes no special distinction between them, will continue to prove useful.

In view of the rapid developments in digital electronics, this second edition concentrates on revising the material on digital signal processing. The sections on digital filters in chapter 9 have been rearranged and expanded, a clear distinction now being made between filters of the finite impulse response (FIR) and infinite impulse response (IIR) types. This is in line with most other recent textbooks on digital filtering. Chapter 10 has been largely rewritten and its new title reflects its broader scope. In particular, I have included material on optimum Wiener and Kalman filtering - topics which, once again, the digital computer has given considerable practical interest. I feel that this final chapter may now reasonably claim to cover, even if only at an introductory level, most of the available linear techniques for signal recovery, estimation and prediction.

I should like to thank Mrs Angela Tyler for all her help with the revised manuscript.

PAUL A. LYNN 